\title{
The Training Needs of Future Secondary Education Teachers in Spain
}

\author{
Francis Ries, Cristina Yanes Cabrera, Miguel Ángel Ballesteros Moscosio \\ Universidad de Sevilla, Spain
}

\begin{abstract}
This paper shows the current situation of the $R \& D$ project 'Analysis of the training model of secondary education teachers: identifying needs and proposals for improvement'. This project is focusing on the analysis, study and design of concrete proposals to assist in decision-making processes at two levels: (a) in the design of methodological strategies within the teaching practice and $(b)$ the inclusion, where appropriate, of training models within the framework of the subjects currently defined in the new Master on Teacher Training for Secondary Schools in Spain. The project started in 2011/2012 and has been performed since then among the students of the new compulsory Master's Degree.

In this context, the present paper aims to study and analyse the training needs perceived by the students of this Master's degree at the University of Seville. This analysis is complemented by a study on the monitoring reports of the Master's degree by the University of Seville and the National Agency for Evaluation. The purpose of the study is to identify the extent to which a future training program (either a Master's degree or any other alternative) must provide the development of skills focused on theoretical knowledge (contents) or the practical development thereof (competencies, abilities, or attitudes).
\end{abstract}

\section{Introduction}

Teacher education has experienced significant changes in many European countries during the Bologna Process of higher-education reform [1,2]. Whether the effects will be positive or negative and what tendencies these reforms have raised in terms of teacher education is still unclear as the empirical evidence on the attainments in many countries is insignificant $[3,4]$. In Spain, the recent launch of the new Master's Degree on Teacher Training for Secondary Education, Vocational Training and Language Teaching in a significant number of universities has become a major challenge.

Being a teacher today does not mean the same as two or three decades ago. Historically speaking Teacher Training for Secondary Education has been a neglected field and vaguely studied in comparison, for example, to Primary Education, or to the studies conducted in other countries like France or United Kingdom. This situation was confirmed in various analyses and reports conducted internationally on the teaching profession. The first one was the OECD report issued in 2004 [1,5] and titled "Teachers Matter: Attracting, Developing and Retaining Effective Teachers". EURYDICE published the second report in 2004 under the title "The Teaching Profession in Europe" [6]. In Spain, the abandonment of the teaching profession for Secondary Education became also visible at the policy level. Until 2009, the existing Teacher Training model had been regulated basically by the Decree 1678/1969 set during Franco's dictatorship creating thus the Institutes of Educational Sciences (ICE), and the Order of 8 July 1971 regulating the activities of these ICE which conferred the Certificate of Pedagogical Aptitude (CAP), a certificate that allowed teaching at Secondary Education level.

As to the actual effectiveness of this model, the results of several studies [7,8] highlight the disorganization, the uselessness and the negative evaluation of this training model $[9,10]$.

During 2009, the Spanish Government restructured therefore the training model of Secondary Education teachers in order to adapt it to the European Higher Education System, establishing a single Master's degree (Máster Universitario en Profesorado en Enseñanza Secundaria Obligatoria y Bachillerato, Formación Profesional y Enseñanzas de Idiomas - MAES), which allows teaching at this education level. The curriculum of the MAES consists of 60 ECTS credits, to be accomplished, preferably, in one year. Future secondary school teachers may access this Master's degree once they have completed a four-year Bachelor's degree in a secondary school subject (mathematics, chemistry, physics, history, etc.). The Spanish teacher-training model is a consecutive model; first students receive general education in order to obtain a degree in their specialty subject or branch of study. At or near the end of this period of study, they enrol in a programme of initial professional training, enabling them to qualify as teachers. They all need to complete 120 hours of general training, 240 hours of more specific contents in relation to their specialty, 100 hours of teaching practice in Secondary School and 60 hours to elaborate the final essay. 
The curriculum of the new Master's degree is based on a Ministerial Order that establishes the requirements for verification of official university degrees, which means that for the first time, the training model for all the Spanish territory was unified. Furthermore, reviewing the contents of this training model it is observable that some of the training principles discussed recently by researchers in Teacher Education have been included $[11,12,13]$.

Five years have passed since the establishment of the MAES in Spain and, consequently, an evaluation of this model is required based, among other things, on the training needs that future teachers perceive as necessary in order to deal with the educational practice and hence contribute to improving the new training process in order to adjust it to the changing contexts in school.

\section{Objectives}

The overall objective of this research is to study and analyse the training needs of the students (future teachers) that enrolled for the MAES degree at University of Seville. In order to complete our main objective, the master students completed an ad hoc questionnaire on aspects directly related to the development of skills that are useful in their future teaching practice, both at personal level and in relation to their previous education. Moreover, the research aims to provide information on these topics and conditions which are contained in the official reports [14] developed in the current legislative framework to comply with the regulations (Article 27 of the Royal Decree 1393/2007 of October $29^{\text {th }}$, as modified by Royal Decree $861 / 2010$ of July $2^{\text {nd }}$ ) and the report posted by ANECA (Agencia Nacional de Evaluación de la Calidad y Acreditación) in 2012 which reflects the findings of a nationwide survey on the implementation of the MAES degree. All these reports collect the opinions and the perceptions of the members of the university community involved in the development of the master's degree.

More specifically we sought:

- To understand the personal and professional reasons that have led and motivated student teachers to enrol in the Master's degree.

- To assess the disciplinary knowledge of future teachers, at theoretical, practical and policy level.

- To analyse the knowledge they have on skills for critical thinking.

- To specify the knowledge they possess in relation to the conflict situations they may encounter in their future practice as teachers, as well as the ability to take decisions in order to resolve such conflicts, and other exceptional situations.

- To know the level of normative, theoretical and practical knowledge in relation to the various elements associated with attention to diversity.
- To analyse the knowledge that these future teachers have in relation to the skills necessary to work and interact with families and the knowledge of the socio-economic environment.

- To complete this whole analysis through the study of the boundary conditions and other elements involved in the processes of teaching and learning designed in the MAES degree.

Briefly, the purpose of the study is to identify the extent to which a future training program (either a Master's degree or any other alternative) must provide the development of skills focused on theoretical knowledge (contents) or the practical development thereof (competences, skills, or attitudes).

The work presented in this article is part of an $R \& D$ project that has been conceived as a platform for analysis, study and design of specific proposals to assist in decision-making processes at two levels: (a) the design of methodological strategies within the teaching practice and (b) the inclusion, where appropriate, of training models within the framework of the subjects currently defined in the Master's Degree.

This national R\&D project started in 2011/2012 and has been performed since then among the students of the new compulsory Master's Degree.

\section{Analysis of the competencies in the Spanish teacher-training model}

The Teacher Training model, as considered above, is structured through a general common body of knowledge (mainly didactical and pedagogical) and explicit subjects specializing the future teachers. For all of them specific competences related to teaching are established. In relation to the objectives of this study we focused on some of them already treated by some authors $[15,16]$. We define competence as a cluster of related abilities, commitments, knowledge, and skills that enable a person to act effectively in a job or situation. It produces tangible results and informs us as to the degree of control achieved [17]. Taking into account the definition of competence, we selected those competencies, which we believe should be present in the initial teacher education at this level.

We are aware that this is only an initial approach, since the knowledge of the training needs identified by the participants in this study can offer new perspectives for further investigations. A 'good teacher' could be described with five 'Ps' (practice, profession, person, partilha - co-work, and public) considering within the training program the practical component, the professional culture, the personal dimensions, the collective logic and the public presence of teachers [18]. Among the possible competencies, we considered those that are more focused on teaching practice, on the individual and 
cooperative work, leaving for a further study those that are linked to the teaching profession. The analysed competencies are: disciplinary knowledge, development of critical thinking, resolving problems and conflicts in special education contexts, decisionmaking capacity, dealing with diversity, communication and development of collaborative processes in the institutional framework, work with the community and with families and, finally, knowledge of the environment.

The disciplinary knowledge is one of the components of specialized pedagogical knowledge and it derives from the teacher's ability to select and properly analyse the subjects and from his/her ability to adapt the meaning and to identify its social and educational validity [19]. All closely related to the ability to conduct a curriculum planning that includes all components of the teaching-learning process. In addition, such knowledge is understood as theoretical knowledge per se, and, among other functions, has an impact focused on practice [20].

Although, undoubtedly, in addition to acquiring disciplinary knowledge and pedagogical and didactic skills, nowadays, secondary education teachers are expected to develop other specific skills to respond to the continuing demands emanating from their own practice as teachers. In this context, we could address the ability to develop and create the students' critical thinking. Currently, in the teaching-learning process students continue to play a passive role. Within their traditional training, most of the time the students end up memorizing concepts without being able to deal with situations and problems with criticality and reflection [21]. In this sense, and based on former studies [22,23], we have characterized the skills of critical thinking as: the ability of verbal reasoning and analysis of arguments, ability to explain, to predict and to control events of everyday life and to reflect on them and the ability in recognizing and defining a problem from certain data, the selection of relevant information and contrasting the different alternative solutions and their results. The last ability would be closely linked to the skills that we have noted as resolving problems and conflicts in special education contexts and decision-making ability.

As several studies have shown the work conditions of teaching have changed during the last decades and consequently the teachers have great difficulty solving, for example, conflicts in school. In our modern societies and in the context of netsocialization innovative elements are integrated that mark enriching trends, although not without conflicts, such as immigration and intercultural relations [24].

As a result, another factor to be considered in teaching practice that affects the initial training is the attention to diversity covered by the Act of Education (LOE) 2/2006. The Act states that education is the means to encourage individual differences with the goal of social cohesion. Subsequently this involves a specific support to students with special educational needs, disabilities, with high intellectual level, or from other countries [25].

In this sense, research conducted in some Spanish regions, such as Extremadura and the Canary Islands, show that immigration is a very important component to be considered in the planning of any teaching activity [26]. Recent studies have shown that almost $80 \%$ of the teachers expressed their concern for training in intercultural education, which only serves to emphasize the immediate need to design training plans corresponding to this demand [27]. It is this sense educational action should not be installed as part of an action-reaction process, but must be preventive and proactive [28].

Finally, one of the essential aspects barely studied at this educational level refers to the processes of horizontal communication between professionals, as well as their relationships with the families of students. In this sense, the departmental structure should be a forum for teachers to socialize and organize their teaching. By contrast, teachers do not feel supported, and rarely find a place at school to share their experiences or to discuss their concerns in order to find a cooperative solution. Therefore, teachers should conceive their interrelated practice with the school as a whole and with the practice of other colleagues. That is the reason that explains why all aspects relating to the personal nature of teaching practice must be taken into consideration [29], aspects such as the participation of teachers in school life, the collaborative work with other teachers, and the establishment of relationships with other agents that affect the education of students, such as families and other professionals. These processes should be included in the initial training of teachers and their analysis has to be based on the needs currently identified by teachers [30].

Regarding the relations with families, only a few studies focus on relationships and cooperative actions with teachers, and they are mostly focused on primary education [31]. In this direction the studies developed by Bronfenbrenner, Cochran and Cross are an important benchmark within the Family Development Credential Program. They conducted research on the relations between school and the family, exhibiting the differences between the teachers' and the parents' perceptions in regard for the education of their children.

Indeed, this aspect is largely conditioned by the type of school (rural or urban), or by the socioeconomic status of students. In any case, it is very important that future teachers require the ability to be very familiar with the environment. According to the same author, one of the elements that commonly lead to failure in the educational practice is the lack of knowledge of the environment in which teachers 
develop their teaching (what students think, what aspects determine the dynamics of the classroom, etc.). Therefore, the most effective approach is to understand the complexity of factors that influence the dynamics of the classroom and to analyse and evaluate the importance of each of these factors in order to obtain the adequate climate and the learning outcomes to be achieved [32].

\section{Methods}

\subsection{Participants}

In total 244 students (146 women and 98 men; $M_{\text {age }}=28.07, S D=4.73$ ) enrolled in the generic module of the MAES at the University of Seville, participated during the academic year 2010/2011 in this study. The vast majority of the surveyed students (86.1\%) chose this Master's degree, as it is a requirement for future teaching in Secondary Schools after passing a state examination.

\subsection{Instrument}

In order to elaborate the questionnaire, 74 items were created according to the objectives of our study. This initial generation of the items that composed the questionnaire was based on a literature review on the aspects raised in the objectives of this research. Subsequently, four experts conducted their evaluations independently from each other in order to discover difficulties related to the lack of relevance of the items, as well as to the format of the data. Several items were ambiguous or did not possess enough information for evaluation and were eliminated, thus respecting in total 64 items.

The failure to find a measuring instrument to assess all the dimensions led us to create this ad hoc questionnaire. All items are reflected in a Likert-type scale from 1 (Strongly disagree) to 7 (strongly agree). The reliability of the scale consisted of this 64-item scale was calculated with SPSS 18.0, obtaining a Cronbach alpha coefficient with an excellent value of $\alpha=.939$.

An exploratory factorial analysis extracted nine factors or dimensions that explain a total of 78,347\% of the variance of the data. The factorial structure of the questionnaire proved to be stable and the nine dimensions represent very relevant aspects of initial teacher training for Secondary Education:

- Dealing with diversity

- Resolving problems and conflicts in special education contexts

- $\quad$ Previous experience of critical thinking

- Communication and development of collaborative processes in the institutional framework

- Knowledge of the environment
- Work with the community and with families

- Decision-making capacity

- Disciplinary knowledge

- Knowledge of critical thinking

\section{Results}

In order to meet the proposed objectives, this R\&D project contained four work packages (WP).

The first WP involved an analysis of the evolution of educational policies regulating the initial teacher training and the teaching practices in Spain. This analysis led us to conduct comparative studies with other European systems, for example Luxembourg, where a two-year induction phase combines concurrently one-year teaching practice in schools.

During the second and the third stage of our project, students enrolled in the Master's degree completed the before-mentioned questionnaire. The data collection and analysis still need to be completed through a second and third wave at the end of the project.

Finally, the fourth phase of the present study has not been implemented yet and it will focus on establishing proposals based on our results in order to help improving the teacher-training model for secondary schools in Spain.

\subsection{Descriptive results}

The descriptive analysis performed shows that in the first dimension disciplinary knowledge, the bestvalued item is previous theoretical training. The participants in our study claim to have a good previous training in their discipline with a mean score of $M=5.29$. But with an average of $M=3.51$ students report that their academic training prior to the MAES has not provided them with sufficient information on the prescribed legislative level in secondary curriculum, thus forming the weak point in this dimension. In relation to this first research objective it appears that from the theoretical point of view the students perceive have good knowledge of their subjects. In relation with the practical disciplinary knowledge participants affirm that their level is lower than the theoretical concepts of their subject. As for the set of rules in their subject (curriculum) the results indicate a clear deficiency among students of MAES. Concerning the average score of this dimension, it seems obvious that the students show an acceptable level of knowledge of their subject discipline $(M=4.50)$ prior to enrolling to the MAES.

In relation to the dimension previous experience in critical thinking, the mean score is $M=4.53$. It should be highlighted that the participants in this study had a prior academic training that has enabled them to acquire acceptably different aspects of 
working with critical thinking. Overall the results indicate $(M=3.98)$ that they have little knowledge about critical thinking.

In relation to the objective to assess the knowledge possessed by participants in relation to conflict situations that can be found in their future practice as teachers, we see that all aspects are reaching an average less than four. From the results obtained and the fact that their initial training on how to solve problems and conflicts in difficult educational contexts $(M=3.77)$ is incomplete, it can be stated that future teachers are not adequately prepared in this area and a future training activity should include these aspect to ensure adequate preparation.

Similarly, certain gaps are identified in relation to the capacity of decision-making in order to resolve such conflicts, and other special situations $(M=3.99)$. The students feel that their training has not provided them with adequate skills with respect to this dimension $(M=3.34)$.

Another objective of this study was to determine the level of normative, theoretical and practical knowledge on the various elements associated with attention to diversity. The descriptive results show very little knowledge about this issue, and this is reflected in low scores in all aspects and consequently in the average score $(M=2.77)$. Given the increasing influx of immigrants to Spain and consequently to the educational centres, we believe that future teachers should be better prepared to meet this challenge. Similarly, an appropriate level of knowledge on this dimension would provide future teachers specific tools to support students with special educational needs, disabilities, and high intellectual abilities.

The dimension of communication and collaborative processes in the institutional framework achieves the highest average score of all dimensions $(M=5.34)$. This result leads to state that the level of knowledge on this subject is quite good among the participants in our study.

Finally it was aimed to analyse the knowledge that future teachers have in relation to the ability to work and interact with families and the knowledge of the environment. Working with family is between the lower dimensions of full scale $(M=3.31)$. Again the students feel they have few skills acquired in their previous training with respect to this question $(M=2.79)$. Within the last dimension knowledge of the environment, it can be seen that the least valued aspect is again insufficient academic background on this dimension $(M=2.79)$.

\subsection{Analysis of official reports}

At the University of Seville the first edition of MAES launched for the academic year 2009-2010. As reflected in the official report, the second edition, with about 500 students, substantially improved the first one: teaching was included in the course load of the involved teacher and organizational aspects were improved. The reports that have been released over the years have been based on information gathered from some of the coordinators of each of the modules, from meetings with teachers and the legal representatives of students and other administrative staff's comments involved in the MAES.

The main deficiencies identified by the students in these first editions provide evidence that a high percentage of students do not perceive that they are being offered in some subjects content they consider useful for their future professional development.

Students complained about issues such as the fragmentation of some subjects and the repeating of contents in several subjects, which stands out as a significant lack of coordination among the faculty members who taught in the Master's degree.

Occasionally, students completed a complaint form about the training of the teachers who teach in the MAES, revealing that in this case they did not have enough training to teach the module.

Finally, one issue to highlight is the period of teaching practice. Students generally point to the work of the professional tutors at school as "highly satisfactory", which shows that, as a subject of the MAES, it appears to meet the expectations of the students and the training expectations.

Moreover, the ANECA published in 2012 a document that was posted to inform about the situation of the MAES after its launch in the Spanish universities, both public and private. In this report, one of the key issues that were reflected concerns weaknesses identified in relation to the issue of competences. As the application of the paradigm of basic competences (PCB) is required for Secondary Education Teachers, the teachers involved in the MAES should also be required to use them in their teaching. In this sense, the teaching-learning process and the assessment should be referred to one or more of the eleven competencies listed in the Order ECI/3858/2007 [33].

Therefore, in the ANECA report, the requirement in the LOE (Ley Orgánica de Educación - Law of Education) in relation to teacher training states that an adequate training must be guaranteed to meet the challenges of the educational system, to adapt the teachings to the new requirements and to ensure the acquisition of all the competencies specified in the Order ECI/3858/2007, _which forces to plan the teaching-learning processes in order to ensure coherence and coordination of the lessons taught in the Master's degree.

Some other weaknesses were identified in the MAES at the Spanish universities. Many overlapping of content occurs between the different subjects of the MAES's modules. The number of teachers who teach a course should be taken into account. If 
several teachers share a subject, the problems of overlapping and incoordination increase. The methodology and training activities, particularly in view of the graduates, are quite traditional and not related to a future application in teaching practice. Generally, students valued very positively the period of teaching practices, and as they perceive it as the most productive teaching module.

\section{Conclusions}

A quickly changing society has meant that teachers in Spain have found themselves facing a range of new challenges in the classroom. Among the most significant, has been the inclusion of children with special educational needs into schools and the increase in the numbers of students from different ethnic and cultural backgrounds. New technologies have emerged and influence the way young people communicate and learn and teachers have been required to adjust their teaching to this new reality. An increasingly diverse society, altering family structures and the rise of new social problems have added to the complexity of the teacher's role [34].

After the present study, we can conclude that the results allow us to obtain a generalized view of the future professional training profile of Secondary Education Teachers as well as of the situations that involve the development of the recent compulsory Master's degree. Indeed, the participants in this study responded that what they mainly claim is the acquisition of certain skills and competencies focused primarily on the practical exercise. This fact is not only shown through the result of questionnaires, but also evidenced by the analysis of the official documents that completed this study. These documents also reflect that the theoretical training module of the Master's degree does not offer the students enough skills to face their future teaching practice. The students do not only perceive this issue while they are studying the MAES, but also the final reports coincide.

In relation to the teaching practices during the Master's degree, the results of our research again agree with the data obtained from the reports. The students affirm that they indeed learn skills that are considered useful for their future teaching. The existence of professional and academic tutors, and certainly if there is good coordination between them, is providing an essential element for the training process of our future teachers. Certainly the theoretical training is fundamental, but it might be necessary to check if the contents that are actually taught are responding to the skills and competencies established in the curricula of each of the theoretical modules. Consequently, as it has been demonstrated in the present study, it is essential to start working on coordinating the content and the subjects.
Finally we believe that in response to the needs identified in both the results obtained from the questionnaires, and after analysing the reports, the practical teaching experience is crucial, compared to other content that are being offered in some modules of the Master's degree. This is also confirmed by other studies of the MAES that have been recently published and undertaken at the Universidad Autónoma and the Universidad Pontíficia Comillas, both in Madrid [35]. Data from our study have precisely shown that participants have clearly perceived more shortcomings in the practical and regulatory aspects controlling this teaching practice. Reconsidering the abilities, skills and attitudes acquired in their training prior to the Master's degree, the participants in this research outline the flaws of such training, manifested by the level of knowledge on the different aspects that were collected through the questionnaire.

\section{Acknowledgment}

The work described in this report was undertaken by a research group from the Faculties of Educational Sciences at the Universities of Seville and Malaga (Spain) and is being supported by a grant from the Ministry of Science and Innovation (Spain), Ref.: EDU2011-28946.

\section{References}

[1] P. McKenzie, P. Santiago, P. Sliwka and H. Hiroyuki, Teachers matter: Attracting, Developing and Retaining Effective Teachers, OECD, Paris, 2005.

[2] J. Enders et al., The Extent and Impact of Higher Education Curricular Reform Across Europe, Center for Higher Education Policy Studies, Enschede, 2006. http://ec.europa.eu/education/pdf/doc240_en.pdf

[3] J. Bauer and M. Prenzel, "European Teacher Training Reforms". Science, 336, 2012, pp. 1642-1643.

[4] J. Looney and J. Gordon, "On becoming a teacher: a lifelong process". European Journal of Education, 46, 2011, pp. 433-439.

[5] OECD, Education and training policy. Paris, 2005. http://www.oecd.org/edu/school/34990905.pdf

[6] EURYRDICE, The teaching profession in Europe: Profile, trends and concerns. Report I: Initial training and transition to working life, Brussels, 2004.

[7] M. Casas, "La formación del profesorado diseñada por la LOGSE. Experiencias formativas de geografía e historia a través de los CCP experimentales". Íber. Didáctica de las Ciencias Sociales, Geografía e Historia, 42, 2004, pp. 57-67. 
[8] J. Marrero, "Lecciones aprendidas de la experiencia del Curso de Cualificación Pedagógica (CCP) en la Universidad de la Laguna (1995-2008)". Monográficos Escuela, 2008, pp. 21-32.

[9] F. Imbernón, "La formación inicial del profesorado de secundaria ¿sigue siendo un tema pendiente?" Aula de Innovación Educativa, 161, 2007, pp. 5-6.

[10] M. Gonzalez Sanmamed, "Una nueva oportunidad para la formación inicial del profesorado de Educación Secundaria”. Revista de Educación, 350, 2009, pp. 57-78.

[11] P. Laursen, Student Teachers' Conceptions of Theory and Practice in Teacher Education". Paper presented at the biannual ISATT conference, Brock University, July, 2007. http://www.isatt.org/.../Laursen_StudentTeachersConcepti onsofTheoryan dpractice.pdf

[12] S.H. Feinman-Nemser, "Teacher learning: How do teachers learning to teach?" In: M. Cochran-Smith, S.H. Feinman-Nemser, D.J. McIntyre and K.E. Demers, (Eds.) Handbook of Research on Teacher, 2008, pp.45-69.

[13] C. Marcelo, "Formalidad e informalidad en el proceso de aprender a enseñar". Revista de Educación, 350, 2009, pp. 31-55.

[14] Secretariado de Máster Universitario, "MemoriaInforme de valoración del Master Universitario en Profesorado de Enseñanza Secundaria Obligatoria y Bachillerato, Formación Profesional y Enseñanzas de Idiomas (MAES). Segunda edición: curso 2010-2011". Centro Internacional de Postgrado y Doctorado, Universidad de Sevilla, 2012.

[15] P.H. Perrenoud, Diez nuevas competencias para enseñar. Barcelona: Graó, 2004.

[16] M. Zabalza, Competencias docentes del profesorado. Calidad y desarrollo profesional. Madrid: Narcea, 2003.

[17] L. Buendia, et al., "Valoración por parte del alumnado de las competencias que se pretenden conseguir con el Master Universitario del Profesorado de Educación Secundaria Obligatoria, Bachillerato, Formación Profesional y Enseñanzas de Idiomas". Bordón, 63, 2011, pp. 57-74.

[18] A. Nóvoa, "Para una formación de profesores construida dentro de la profesión". Revista de Educación, 350,2009 , pp. 203-218.

[19] F. Imbernón, La formación y el desarrollo profesional del profesorado. Hacia una nueva cultura profesional. $6^{\mathrm{a}}$ edición. Barcelona: Graò, 2004.

[20] K. Smith and E. Hodson, "Theorising practice in initial teacher education". Journal of Education for Teaching, 36, 2010, pp. 259-275.

[21] K. Zeichner, "Rethinking the Connections Between Campus Courses and Field Experiences in College- and University-Based Teacher Education". Journal of Teacher Education, 61, 2010, pp. 89-99.
[22] A.M. Nieto, C. Saiz and B. Orgaz, "Análisis de las propiedades psicométricas de la versión española del HCTAES-Test de Halpern para la evaluación del pensamiento crítico mediante situaciones cotidianas". Revista Electrónica de Metodología Aplicada, 14, 2009, pp. 1-15.

[23] M.J. Beltrán and N.Y. Torres, "Caracterización de habilidades de pensamiento crítico en estudiantes de educación media a través del Test HCTAES". Revista del Instituto de Estudios en Educación Universidad del Norte, 11, 2009, pp. 66-85.

[24] L. Darling-Hammond, "Teacher Education and the American Future. Journal of Teacher Education, 61, 2010, pp. 35-47.

[25] R. Castaño, "El Curriculum y la Atención a la Diversidad en las etapas de la Educación Básica, Primaria y Secundaria Obligatoria, en el marco de la Ley Orgánica de Educación". Hekademos: Revista educativa digital, 6, 2010, pp. 5-26.

[26] A.J. Baigorri, M. Chaves and R. Fernández, "Yo y el otro: actitudes ambivalentes hacia la inmigración entre los estudiantes de secundaria en Extremadura". Aposta: Revista de ciencias sociales, 9, 2004, pp. 1-11.

[27] M.A. Calatayud, "Formación en Educación Intercultural: la voz del profesorado". Aula abierta, 88, 2006, pp. 73-84

[28] F. Molina, "Nuevos conflictos sociales y su presencia educativa: análisis sociológico y reflexiones para la intervención”. C \& E: Cultura y educación, 17, 2005, pp. 213-223.

[29] J.M. Escudero, "La formación del profesorado de Educación Secundaria: contenidos y aprendizajes docents". Revista de Educación, 350, 2009, pp. 79-103.

[30] M. Cochran-Smith and C. Power, "New Directions for Teacher Preparation". Educational Leadership, 67, 2010, pp. 6-13.

[31] C. Forest and F.J. García Bacete, Comunicación cooperativa entre la familia y la escuela. Valencia: Edicions Culturals Valencianes, S.A., 2006.

[32] J.M. Esteve, "La formación de profesores: bases teóricas para el desarrollo de programas de formación inicial”. Revista de Educación, 350, 2009, pp. 15-29.

[33] ANECA, Sobre la implantación del Máster Universitario de Formación del Profesorado de Educación Secundaria Obligatoria, Bachillerato, Formación Profesional y Enseñanza de Idiomas. Análisis de situación y propuestas de mejora, Madrid, 2012. http://www.didactica-ciencias sociales.org/posgrado_fitxers/Informe_Master_Secundaria -ANECA.pdf 
International Journal for Cross-Disciplinary Subjects in Education (IJCDSE), Volume 5, Issue 2, March 2014

[34] J. Gimeno, La educación que aún es posible. Morata, Madrid, 2005.

[35] J. Ayuso Manso and E. Martín Ortega, “Assessment of the Master Program for Secondary Teachers: case study in two universities". Revista de Educación, 364, 2014, pp. 145-169. 